\title{
Potentials of rose (Rosa damascena) petals and receptacles extract as antioxidant and antihyaluronidase
}

\author{
Desi Yustra Sari Dewi ${ }^{1}$, Chrismis Novalinda Ginting ${ }^{* 1}$, Linda Chiuman ${ }^{1}$, \\ Ermi Girsang $^{1}$, Rr. Anisa Siwianti Handayani ${ }^{2}$, Wahyu Widowati ${ }^{3}$ \\ ${ }^{1}$ Faculty of Medicine, Universitas Prima Indonesia \\ Jl. Belanga No. 1 Simp. Ayahanda, Medan 20118, North Sumatera, Indonesia \\ ${ }^{2}$ Aretha Medika Utama, Biomolecular and Biomedical Research Center \\ Jl. Babakan Jeruk II No. 9, Bandung 40163, West Java, Indonesia \\ ${ }^{3}$ Medical Research Center, Faculty of Medicine, Maranatha Christian University \\ Jl. Prof. Drg. Surya Sumantri No. 65, Bandung 40164, West Java, Indonesia
}

\begin{abstract}
Free radicals affect aging by unspecific lead breakdown to macromolecules, like DNA, lipids, and proteins. The degradation of the extracellular matrix affects skin aging and correlated with the hyaluronidase enzyme. Rose (Rosa damascena) petal extract and rose receptacle extract can scavenge free radicals, thus hindering the aging process. This study examined phenolic and flavonoid content, the antioxidant, anti-hyaluronidase potential from rose petal extract (RPE) and rose receptacle extract (RRE) inhibiting skin aging. In this study, hydrogen peroxide $\left(\mathrm{H}_{2} \mathrm{O}_{2}\right)$ scavenging activity assay was done to analyze the antioxidant activity. Futhermore, the hyaluronidase inhibitory assay was done to analyse the antiaging activity. The characteristic of RPE and RRE were measured the phenolics and flavonoids content. The phenolics content of RPE and RRE were $9.66 \mu \mathrm{g} \mathrm{GAE} / \mathrm{mg}$ RPE and $4.31 \mu \mathrm{g}$ GAE/mg RRE, respectively, while the flavonoids content of RPE and RRE were $1.22 \mu \mathrm{g}$ QE/mg RPE and $0.59 \mu \mathrm{g} \mathrm{QE} / \mathrm{mg} \mathrm{RRE}$, respectively. The median inhibitory $\left(\mathrm{IC}_{50}\right) \mathrm{of}_{2} \mathrm{H}_{2} \mathrm{O}_{2}$ scavenging of RPE $(207.99 \mu \mathrm{g} / \mathrm{mL})$ was more active than RRE $(348.24 \mu \mathrm{g} / \mathrm{mL})$. RPE's anti-hyaluronidase (IC 50 : 51.68 $\mu \mathrm{g} / \mathrm{mL}$ ) was as effective as RRE ( $\left.\mathrm{IC}_{50}: 51.98 \mu \mathrm{g} / \mathrm{mL}\right)$. Antioxidant and antiaging activities from RPE and RRE are promising natural agents for aging therapy.
\end{abstract}

Keywords: Antioxidant, antiaging, hyaluronidase, Rosa damascena

\footnotetext{
*Corresponding author:

Chrismis Novalinda Ginting

Faculty of Medicine, Universitas Prima Indonesia

J1. Belanga No. 1 Simp. Ayahanda, Medan 20118, North Sumatera, Indonesia

Email: chrismis@ unprimdn.ac.id
} 


\section{INTRODUCTION}

Aging is a natural process that cannot be avoided by anyone. Environmental changes that occur globally, increased air pollution, and the depletion of the ozone layer that causes direct sun radiation hit on human skin are thought to cause accelerated cell degeneration, ultimately leading to premature aging. Many factors cause premature aging, including heredity, health, endurance, mental health, free radicals, and behavior/lifestyle (Widowati et al., 2018a).

Many people use cosmetics to prevent premature aging. However, most cosmetics use synthetic ingredients so that they will have side effects and are not safe when used in the long run. Therefore, cosmetics made from natural ingredients with antioxidant and antiaging activities are needed (Pujimulyani et al., 2020).

There have been many studies that use natural ingredients to prevent aging. Benefits taken from these natural ingredients are antioxidant properties because they can bind to free radicals. There are a variety of plants that have antioxidant and antiaging effects. One of them is a rose (Rosa damascena).

The pharmacological effects of roses based on their chemical content include: antiviral, antibacterial, antioxidant, antitussive, relaxant, hypnotic, and antidiabetic effects. Rose vapor therapy can even cure allergies, headaches, and migraines (Boskabady et al., 2011). Ethanol extract of roses at doses of 100,500 , and $1000 \mathrm{mg} / \mathrm{kg}$ has been proven to provide analgesic effects on mice that work centrally. Analgesic effects that arise thought to be caused by quercetin and kaempferol (Rakhshandeh et al., 2008).

From the problems and research that support it and considering its utilization is still lacking in the medical field, researchers want to know whether the rose petal extract and the base of the rose (Rosa damascena) can function as antioxidant and antiaging (anti-hyaluronidase).

\section{MATERIALS AND METHOD}

\section{Materials}

The subjects of this study were the petal and receptacle extracts of $R$. damascena, which were obtained from Cihideung Rose Farm, West Bandung Regency, Indonesia, and were identified at Herbarium Laboratory, Department of Biology, School of Life Science and Technology, Bandung, West Java, Indonesia. The number of identification letter is 3632/11.CO2.2/PL/2019. The main ingredient used for the $\mathrm{H}_{2} \mathrm{O}_{2}$ scavenging activity assay was hydrogen peroxide (Merck 1.08597.1000), while for the anti-hyaluronidase test was hyaluronidase from bovine testes type IS (Sigma-Aldrich, H3506).

\section{Methods}

\section{R. damascena extract preparation}

The rose petals and receptacles were weighed and mashed up to get the simplicia. The wet weight of rose petals was $1400 \mathrm{~g}$ while the wet weight of rose receptacles was $700 \mathrm{~g}$. Each petal and receptacle of $R$. damascena $250 \mathrm{~g}$ and $90 \mathrm{~g}$, respectively, were soaked and extracted with a maceration method using distilled ethanol $70 \%$. Every $24 \mathrm{~h}$, it was filtered, and the residue was re-macerated until the filtrate was colorless. Then collected filtrate was concentrated by using an evaporator (Zhengzhou Well-known, RE-201D) at $50^{\circ} \mathrm{C}$ to obtain the extract. RPE and RRE yields were $88.56 \mathrm{~g}$ and $2.72 \mathrm{~g}$, respectively. The extracts were stored at $-20^{\circ} \mathrm{C}$ (Asan et al., 2019; Girsang et al., 2019; Liana et al., 2019; Vrianty et al., 2019; Widowati et al., 2018b).

\section{Total phenolic content assay}

Total phenolic content was measured by using the modified Folin-Ciocalteu method. In the sample well, the gallic acid, RPE, and RRE as much as $15 \mu \mathrm{L}$ were mixed with Folin-Ciocalteu's reagent as much as $75 \mu \mathrm{L}$ and sodium carbonate as much as $60 \mu \mathrm{L}$. The blank solution was introduced $135 \mu \mathrm{L}$ of $10 \%$ DMSO and $15 \mu \mathrm{L}$ of gallic acid, RPE, and RRE. The plate was heated for 10 mins at 
$50^{\circ} \mathrm{C}$. Furthermore, the absorbance was determined using a microplate reader (Multiskan Go Thermo Fisher Scientific) at $760 \mathrm{~nm}$. Total phenolic content determined as gallic acid equivalence (GAE) in $\mu \mathrm{g} / \mathrm{mg}$ sample (Widowati et al., 2016; 2017; 2018b; Prahastuti et al., 2019; 2020).

\section{Total flavonoid content assay}

Flavonoid content was conducted using the modified method (Prahastuti et al., 2019; 2020). Briefly, $15 \mu \mathrm{L}$ standard solution (quercetin) made in various concentration $(100 ; 50 ; 25 ; 12.50 ; 6.25$; $3.13 ; 1.56 \mu \mathrm{g} / \mathrm{mL})$, RPE, and RRE $(1000 \mu \mathrm{g} / \mathrm{mL})$ were mixed with $75 \mu \mathrm{L} \mathrm{AlCl}$. The absorbance read at $415 \mathrm{~nm}$. The standard absorbance used to calculate the linear regression equation $(y=a x+b)$ to analyze the sample's flavonoid content. The flavonoid content presented as quercetin equivalence (QE) in $\mu \mathrm{g} / \mathrm{mg}$ sample (Prahastuti et al., 2019; 2020).

\section{Radical scavenging activity of $\mathrm{H}_{2} \mathrm{O}_{2}$}

This assay was measured using a modified method (Utami et al., 2017). Briefly, $60 \mu \mathrm{L}$ of the sample at various concentrations $(500,250,125,62.5,31.25$, and $16.625 \mu \mathrm{g} / \mathrm{mL}), 12 \mu \mathrm{L}$ ferrous ammonium sulfate $(1 \mathrm{mM}), 3 \mu \mathrm{L}$ of $\mathrm{H}_{2} \mathrm{O}_{2} 5 \mathrm{mM}$ were added into the sample well plate. The control well contained $12 \mu \mathrm{L}$ ferrous ammonium sulfate and $63 \mu \mathrm{L}$ DMSO 10\%. It was incubated in a dark room at room temperature for 5 mins. After that, $75 \mu \mathrm{L} \mathrm{1,10-phenanthroline}(1 \mathrm{mM})$ was added into each sample and control well. Then it was incubated again in the same condition for 10 mins. The absorbances were determined at $510 \mathrm{~nm}$ (Asan et al., 2019; Jusri et al., 2019; Liana et al., 2019; Utami et al., 2017). The scavenging activities percentage of samples were calculated using this following formula :

$\mathrm{H}_{2} \mathrm{O}_{2}$ Scavenging Activity $(\%)=(\mathrm{Ac}-\mathrm{As}) / \mathrm{Ac} \times 100$

Ac: control absorbance

As: sample absorbance

\section{Hyaluronidase inhibitory activity}

This activity was measured by a modified method (Widowati et al., 2016, 2017, 2018b; Asan et al., 2019; Liana et al., 2019). A mixture of RPE, RRE at various concentrations (166.67, 83.33, 41.67, $20.83,10.42$, and $5.21 \mu \mathrm{g} / \mathrm{mL})$ each at $25 \mu \mathrm{L}, 3 \mu \mathrm{L}$ hyaluronidase, $12 \mu \mathrm{L}$ phosphate buffer $(300 \mathrm{mM}$, $\mathrm{pH}$ 5.35) was incubated at $37^{\circ} \mathrm{C}$ for 10 mins. Thereupon, $10 \mu \mathrm{L}$ hyaluronic acid substrate (Sigma Aldrich, H5542) was added and incubated again at the same temperature for 45 mins. Then, $100 \mu \mathrm{L}$ acidic albumin was added to stop the reaction. The mixed solution incubated again at room temperature for 10 minutes. The absorbance was read using a wavelength at $600 \mathrm{~nm}$. The inhibition activity was calculated using the following formula:

$$
\begin{gathered}
\text { Elastase Inhibitory Activity }(\%)=(\text { Ac-As }) / A c \times 100 \\
\text { Ac: control absorbance } \\
\text { As: sample absorbance }
\end{gathered}
$$

\section{Statistical analysis}

The value was presented as Mean \pm Standard Deviation. Significant differences between the groups were determined using the Analysis of Variance (One Way ANOVA) followed by Tukey's HSD Post-hoc Test in SPSS software (version 20.0). The results of $\mathrm{H}_{2} \mathrm{O}_{2}$ scavenging and antihyaluronidase activity tests were continued by linear regression analysis to calculate the median inhibitory concentration $\left(\mathrm{IC}_{50}\right)$. 


\section{RESULT AND DISCUSSION}

The percentage of RPE and RRE yield were $35.4 \%$ and $3.02 \%$, respectively. These results indicated that RRE has a better yield than RPE. According to Boskabady et al. (2011), secondary metabolite compounds in $R$. damascena include flavonoids and terpenoids. According to Elfitriani et al. (2020), RPE and RRE contained flavonoids, phenolics, tannins, and alkaloids. In this study, total phenolic and flavonoid content were examined. Total phenolics were conducted by a colorimetric method (Prahastuti et al., 2019; 2020; Widowati et al., 2016; 2017; 2018b). The total polyphenols were quantified using the standard curve of gallic acid (Figure 1). The experiments declared the availability of phenolics in the RPE and RRE were $9.66 \pm 1.26 \mu \mathrm{g}$ GAE/mg RPE and $4.31 \pm 0.25 \mu \mathrm{g} \mathrm{GAE} / \mathrm{mg}$ RRE, respectively. This result was higher than phenolic compounds from methanol extract of fresh flowers reported by Baydar et al. (2013), which was $0.72 \mathrm{mg} / \mathrm{g} \mathrm{dw}$. Rose types affected phenolic content. Yunnan rose $(R$. centifolia), China rose $(R$. chinensis), French rose $(R$. gallica), Rose $(R$. rugosa), White rose $(R$. rugosa) have phenolic content as much as 108.94; 248.8; 111.34; 312.21; $39.47 \mathrm{mg} \mathrm{GAE} / \mathrm{g}$, respectively (Zheng et al., 2018). Their phenolic contents were higher compared to this data result. The phenolic content in plants was correlated with total anthocyanins (Schmitzer et al., 2009). The phenol content of RPE was higher than RRE. This data was validated with previous research that petal of $R$. canina $1954 \mathrm{mg} \mathrm{GAE} / 50 \mathrm{~mL}$ and fruit of $R$. canina $937 \mathrm{mg} \mathrm{GAE} / 50 \mathrm{~mL}$ (Moghaddam and Shaaban, 2018).

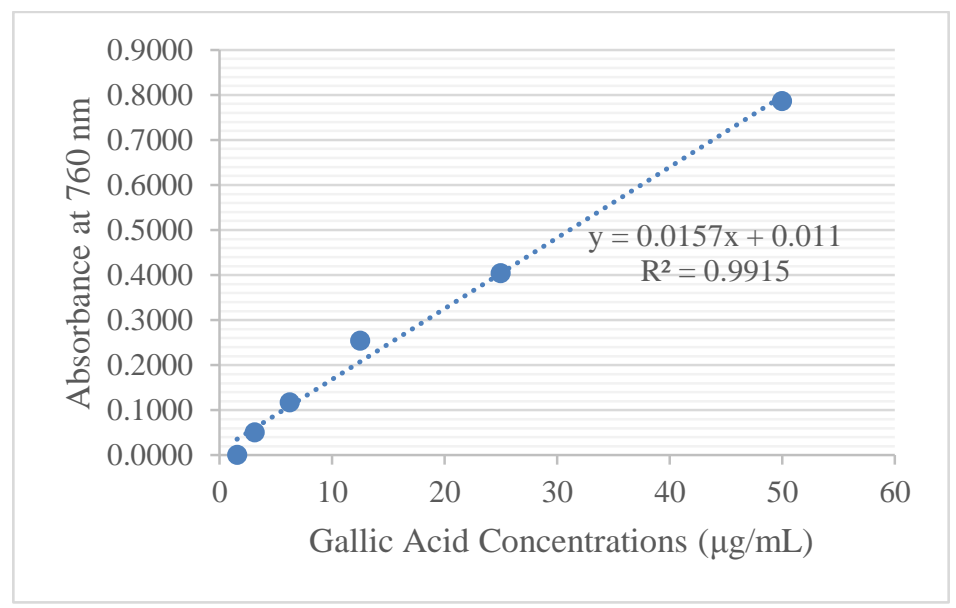

Figure 1. Standard curve of gallic acid

The standard curve of quercetin for total flavonoids determination can be seen in Figure 2. Its quantification declared that the availability of flavonoids in RPE and RRE were $1.22 \pm 0.06 \mu \mathrm{g} Q E / \mathrm{mg}$ RPE and $0.59 \pm 0.03 \mu \mathrm{g}$ QE/mg RRE, respectively. Shameh et al. (2019) reported that the total flavonoid of $R$. canina was $2.53 \mathrm{mg}$ QE/g FW. The flavonoid content of China rose $24.13 \mathrm{mg}$ Catechin equivalent/g (Zheng et al., 2018). This data was in line with previous data that the petal of $R$. canina contained $776 \mathrm{QE} \mathrm{mg} / \mathrm{ml}$ higher than fruit of $R$. canina $450 \mathrm{QE} \mathrm{mg} / \mathrm{mL}$ (Moghaddam and Shaaban, 2018). Different Rosa genotypes contain rich phytochemical compounds that have significant variations in their levels (Shameh et al., 2019). 


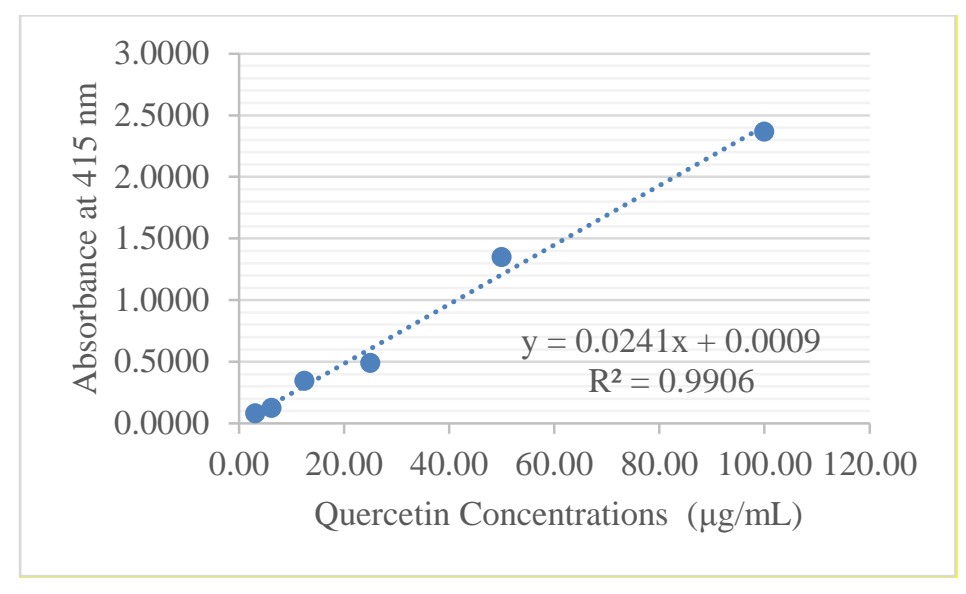

Figure 2. Standard curve of quercetin

Antioxidants are compounds that have the ability to neutralize or reduce the negative effects of free radicals, molecules that have unpaired electrons in an outer circle. From various research results, antioxidants are reported to slow the process caused by free radicals such as the presence of phenolicand flavonoid-rich natural diets (Aryal et al., 2019).

Flavonoid compounds today are commonly studied as antioxidants because of their ability to change or reduce the risk that can be caused by free radicals (Aryal et al., 2019). Patil et al. (2015) reported that RPE showed potent antioxidant as free radical scavenging activities by DPPH, inhibiting pyrogallol red bleach by peroxynitrite, ABTS, xanthine oxidase, superoxide scavenging, and ascorbate iron-induced lipid peroxidation assay. Flavonoids and phenolics, which are polar phytoconstituents from RPE, are well-known antioxidants, free radical scavengers, and antibacterial (Tatke et al., 2015). There are still not many studies of RRE, especially of its antioxidant activity.

The results of $\mathrm{H}_{2} \mathrm{O}_{2}$ scavenging activities from RPE and RRE can be seen in Figure 3, while $\mathrm{IC}_{50}$ values can be seen in Table 1 . RPE is more active in $\mathrm{H}_{2} \mathrm{O}_{2}$ scavenging activity than RRE. At the highest concentration $(500 \mu \mathrm{g} / \mathrm{mL})$, the RPE scavenging activity was at $79.26 \pm 0.10 \%$, while the RRE was at $67.29 \pm 1.76 \%$. According to Marjoni and Zulfisa (2017), RPE was categorized moderate when the $\mathrm{IC}_{50}$ value $101-250 \mu \mathrm{g} / \mathrm{mL}$ and $\mathrm{RRE}$ as a weak antioxidant when the $\mathrm{IC}_{50}$ value was above $250 \mu \mathrm{g} / \mathrm{mL}$.

There are still no studies of $\mathrm{H}_{2} \mathrm{O}_{2}$ scavenging activity in $R$. damascena plants, but some studies reported its antioxidant activity. Alam et al. (2008) reported that $R$. damascena extract has excellent antioxidant activity against DPPH $\left(\mathrm{IC}_{50}=162.525 \mu \mathrm{g} / \mathrm{mL}\right.$ ) comparable to ascorbic acid as a standard drug $\left(\mathrm{IC}_{50}=64.307 \mu \mathrm{g} / \mathrm{mL}\right)$. Rose petal and rose receptacle extracts have antioxidant activity toward 2,2'-azino-bis(3-ethylbenzothiazoline-6sulfonic acid (ABTS) with $\mathrm{IC}_{50}$ value $4.46 \mu \mathrm{g} / \mathrm{mL}$, and 15.49 $\mu \mathrm{g} / \mathrm{mL}$, respectively (Mawarni et al., 2020), which categorized highly active (Marjoni and Zulfisa, 2017). 


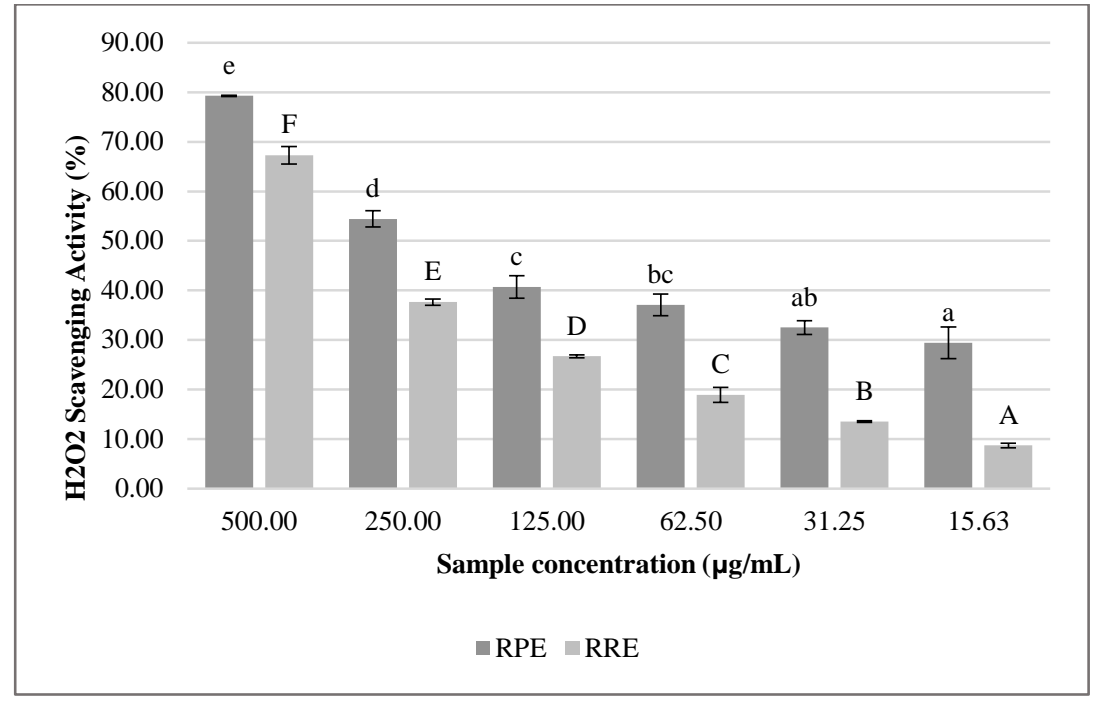

Figure 3. Histogram effects of various rose petal extract and rose receptacle extract concentrations on $\mathrm{H}_{2} \mathrm{O}_{2}$ scavenging activity

*Data are shown as means \pm standard deviation. The different letters (a,ab,bc,c,d,e) among RPE concentrations and differences letters (A,B,C,D,E,F) among RRE concentrations show significant differences at $\mathrm{P}<0.05$ based on Tukey HSD post hoc test.

Table 1. The $\mathrm{IC}_{50}$ values of rose petal extract and rose receptacle extract $\mathrm{H}_{2} \mathrm{O}_{2}$ scavenging activities

\begin{tabular}{lllll}
\hline Sample & Equation & $\mathbf{R}^{\mathbf{2}}$ & $\mathbf{I C}_{\mathbf{5 0}}(\boldsymbol{\mu} \mathbf{g} / \mathbf{m L})$ & $\mathbf{I C}_{\mathbf{5 0}}(\boldsymbol{\mu} \mathbf{g} / \mathbf{m L})$ \\
\hline RPE (replication 1) & $\mathrm{y}=0.1014 \mathrm{x}+28.365$ & 0.99 & 213.36 & \\
RPE (replication 2) & $\mathrm{y}=0.1012 \mathrm{x}+28.952$ & 0.98 & 207.98 & $207.99 \pm 5.38$ \\
RPE (replication 3) & $\mathrm{y}=0.0988 \mathrm{x}+29.982$ & 0.99 & 202.61 & \\
\hline RRE (replication 1) & $\mathrm{y}=0.118 \mathrm{x}+9.6511$ & 0.99 & 341.94 & \\
RRE (replication 2) & $\mathrm{y}=0.1162 \mathrm{x}+10.362$ & 0.99 & 341.12 & $348.24 \pm 11.63$ \\
RRE (replication 3) & $\mathrm{y}=0.1113 \mathrm{x}+9.7472$ & 0.99 & 361.66 & \\
\hline
\end{tabular}

The antioxidant activity test against hydrogen peroxide $\left(\mathrm{H}_{2} \mathrm{O}_{2}\right)$ was determined by using the ferrous ammonium sulfate and phenanthroline reaction. When ferrous ammonium sulfate reacts with phenanthroline, an orange-colored $\mathrm{Fe}^{2+}$-tri-phenanthroline complex is formed. $\mathrm{The}^{\mathrm{H}} \mathrm{H}_{2} \mathrm{O}_{2}$ presence in the reaction will cause the complex not to be formed. So if there is an antioxidant that $\operatorname{traps} \mathrm{H}_{2} \mathrm{O}_{2}$, then the mixture color is orange that show the presence of $\mathrm{Fe}^{2+}$-tri-phenanthroline complex (Stevenie et al., 2019; Asan et al., 2019; Jusri et al., 2019; Liana et al., 2019; Utami et al., 2017).

Hyaluronidase is a proteases group that can degrade the hyaluronic acid (HA), one of the extracellular matrix (ECM) constituents, by catalyzing hyaluronic hydrolysis reactions. It can decreases the viscosity of hyaluronan, thereby increasing ECM and tissue permeability. In this method, the enzyme activity can be detected by measuring HA levels because of its ability to react with albumin acid solution to form turbidity (turbidity). Turbidity that can be read starting from $540 \mathrm{~nm}$ is proportional to the concentration of HA. The enzyme inhibitory activity determined based on the HA higher concentration remaining after the reaction is stopped (Stevenie et al., 2019; Asan et al., 2019; Jusri et al., 2019; Liana et al., 2019; Utami et al., 2017). 
In the anti-hyaluronidase activity test, the final concentration of the sample used was 166.67 $\mu \mathrm{g} / \mathrm{mL} ; 83.33 \mu \mathrm{g} / \mathrm{mL} ; 41.67 \mu \mathrm{g} / \mathrm{mL} ; 20.83 \mu \mathrm{g} / \mathrm{mL} ; 10.42 \mu \mathrm{g} / \mathrm{mL}$; and $5.22 \mu \mathrm{g} / \mathrm{mL}$. The results of antihyaluronidase activities from RPE and RRE can be seen in Figure 4, while $\mathrm{IC}_{50}$ values can be seen in Table 2. The anti-hyaluronidase activity of RPE is as effective as RRE (Figure 4).

Table 2. The $\mathrm{IC}_{50}$ values of anti-hyaluronidase activities of rose petal extract and rose receptacle extract

\begin{tabular}{ccccc}
\hline Sample & Equation & $\mathbf{R}^{\mathbf{2}}$ & $\mathbf{I C}_{\mathbf{5 0}}(\boldsymbol{\mu g} / \mathbf{m L})$ & $\mathbf{I C}_{\mathbf{5 0}}(\boldsymbol{\mu g} \mathbf{g} \mathbf{m L})$ \\
\hline RPE (replication 1) & $\mathrm{y}=0.3277 \mathrm{x}+32.002$ & 0.99 & 54.92 & \\
RPE (replication 2) & $\mathrm{y}=0.3274 \mathrm{x}+32.862$ & 0.99 & 52.35 & $51.68 \pm 3.62$ \\
RPE (replication 3) & $\mathrm{y}=0.3447 \mathrm{x}+33.529$ & 0.98 & 47.78 & \\
\hline RRE (replication 1) & $\mathrm{y}=0.4164 \mathrm{x}+27.472$ & 0.96 & 54.10 & \\
RRE (replication 2) & $\mathrm{y}=0.4658 \mathrm{x}+27.165$ & 0.99 & 49.02 & $51.98 \pm 2.64$ \\
RRE (replication 3) & $\mathrm{y}=0.4334 \mathrm{x}+27.107$ & 0.99 & 52.82 & \\
\hline
\end{tabular}

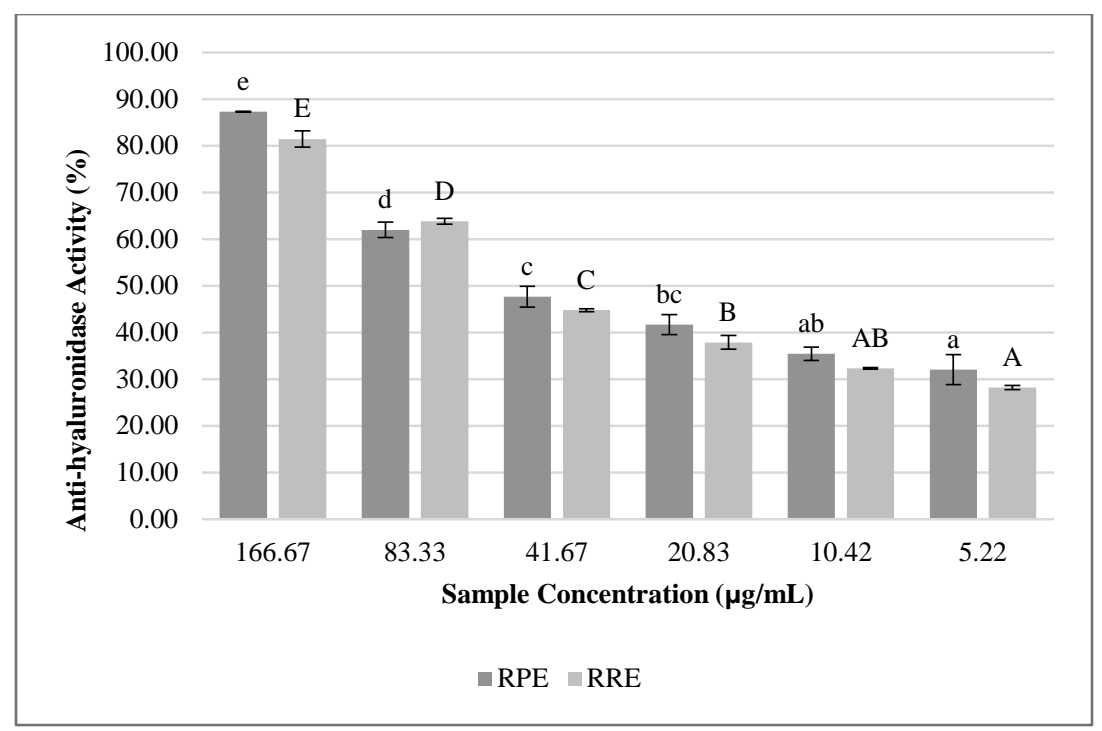

Figure 4. Effects of various rose petal extract and rose receptacle extract concentrations on the anti-hyaluronidase activity

*Data are shown as means \pm standard deviation. Different letter (a,ab,bc,c,d,e) among RPE concentrations and different letter (A,AB,B,C,D,E) among RPE concentrations show significant differences at $\mathrm{P}<0.05$ based on Tukey HSD post hoc test.

At the highest concentration $(166.67 \mu \mathrm{g} / \mathrm{mL})$, RPE had an anti-hyaluronidase activity of $87.27 \pm$ $1.16 \%$, followed by an RRE of $81.44 \pm 3.48 \%$. The $\mathrm{IC}_{50}$ value of RPE and RRE were categorized active when $\mathrm{IC}_{50}$ value reaches $50-100 \mu \mathrm{g} / \mathrm{mL}$ (Marjoni and Zulfisa, 2017).

There are still no studies of hyaluronidase activity in $R$. damascena plants, but some studies reported its antiaging activity. Rozalia et al. (2016) reported that $R$. damascena has antiaging activity inhibiting $80 \%$ of collagenase activity at $100 \mu \mathrm{g} / \mathrm{mL}$. RPE and RRE had an anti-elastase activity with the $\mathrm{IC}_{50}$ value of $17.51 \mu \mathrm{g} / \mathrm{mL} ; 58.91 \mu \mathrm{g} / \mathrm{mL}$ (Mawarni et al., 2020). Scotti et al. (2016) reported that polyphenolics and flavanoids act as contributing factors eliciting hyaluronidase inhibition. It also 
reported that dimeric salicarinin $\mathrm{A}, \mathrm{B}$, and $\mathrm{C}$ had strong potential to inhibiting hyaluronidase enzyme based on $\mathrm{IC}_{50}$ value of $1.6 \pm 0.1,1.6 \pm 0.2$, and $2.5 \pm 0.2 \mu \mathrm{M}$, respectively.

\section{CONCLUSION}

The total phenolic content in this study were $9.66 \pm 1.26 \mu \mathrm{g}$ GAE/mg RPE and $4.31 \pm 0.25 \mu \mathrm{g} \alpha$ $\mathrm{GAE} / \mathrm{mg} \mathrm{RRE}$, while the total flavonoid contents were $1.22 \pm 0.06 \mu \mathrm{g} \mathrm{QE} / \mathrm{mg} \mathrm{RPE}$ and $0.59 \pm 0.03 \mathrm{mg}$ QE/g RRE. In the $\mathrm{H}_{2} \mathrm{O}_{2}$ scavenging activity, RPE was more active than RRE. In the anti-hyaluronidase activity, RPE was as effective as RRE. Overall, RPE and RRE possess antioxidant and antihyaluronidase activities.

\section{ACKNOWLEDGEMENT}

This research was supported by Aretha Medika Utama, Biomolecular and Biomedical Research Center, Bandung, Indonesia, for laboratory facilities and research methodology. We are thankful to Dewani Tediana Yusepany, Dwi Surya Artie, Ika Adhani Sholihah, Alya Mardhotillah Azizah, Kamila Yashfa Gunawan, Seila Arumwardana, and Jenifer Kiem Aviani for their valuable assistance.

\section{REFERENCES}

Alam, M., Nyeem, M., Awal, M., Mostofa, M., Alam, M., Subhan, N., \& Rahman, M. M. (2008). Antioxidant and hepatoprotective action of the crude ethanolic extract of the flowering top of Rosa damascena. Oriental Pharmacy and Experimental Medicine, 8(2):164-170.

Aryal, S., Baniya, M.K., Danekhu, K. Kunwar, P., Gurung, R., \& Koirala, N. (2019). Total phenolic content, flavonoid content and antioxidant potential of wild vegetables from western Nepal. Plants, 8(9):1-12.

Asan, T., Lister, I. N. E., Fachrial, E., Amalia, A., Widowati, W., Samin, B., \& Liena, L. (2019). Potency of black soybean (Glycine max (L.) Merr) extract and daidzein as antioxidant and antihyaluronidase. Majalah Obat Tradisional, 24(1):52-58.

Baydar, N. G., \& Baydar, H. (2013). Phenolic compounds, antiradical activity and antioxidant capacity of oil-bearing rose (Rosa damascena Mill.) extracts. Industrial Crops and Products, 41(1): 375380.

Boskabady, M. H., Shafei, M. N., Saberi, Z., \& Amini, S. (2011). Pharmacological effects of Rosa damascena. Iranian Journal of Basic Medical Sciences, 14(4):295-307.

Elfitriani, E., Raif, A., Ginting, C. N., \& Ikhtiari, R. (2020). Evaluation of antioxidant and anticollagenase activity of Rosa damascena L. flower petal and receptacle extract. F1000Research, 9: 1-7.

Girsang, E., Lister, I. N. E., Ginting, C. N., Khu, A., Samin, B., Widowati, W., Wibowo, S., \& Rizal, R. (2019). Chemical Constituents of snake fruit (Salacca zalacca (Gaert.) Voss) peel and in silico antiaging analysis. Molecular and Cellular Biomedical Sciences, 3(2):122-128.

Jusri, R., Widodo, W. S., Widowati, W., Armansyah, A., Sormin, D. E., Fachrial, E., \& Lister, I. N. E. (2019). Comparison of antioxidant and anti-hyaluronidase potentials of pineapple core extract (Ananas comosus (L.) Merr.) and luteolin. Majalah Kedokteran Bandung, 51(2):63-69.

Liana, L., Rizal, R., Widowati, W., Fioni, F., Akbar, K., Fachrial, E., \& Lister, I. N. E. (2019). Antioxidant and anti-hyaluronidase activities of dragon fruit peel extract and kaempferol-3-O rutinoside. Jurnal Kedokteran Brawijaya, 30(4):247-252.

Mawarni, E., Ginting, C.N., Chiuman, L., Girsang, E., Handayani, Rr.A.S., \& Widowati, W. (2020). Antioxidant and elastase inhibitor potential of petals and receptacle of rose flower (Rosa damascena). Pharmaceutical Sciences and Research (PSR), 7 (2):105 -113.

Marjoni, M.R. \& Zulfisa, A. (2017). Antioxidant activity of methanol extract/fractions of Senggani leaves (Melastoma candidum D. Don).Pharmaceutica Analytica Acta. 8(8):1-6.

Moghaddam, E.H. \& Shaaban, M. (2018). The determination of flavonoid components, total phenolic

Pharmaciana Vol. 10, No. 3, Nov 2020, Page. 343-352 
content, and antioxidant capacity in dog rose (Rosa canina L.) in Lorestan province. Herbal Medicines Journal 3,(3):85-91.

Patil, P. S., Tatke, P. A., \& Gabhe, S. Y. (2015). In vitro antioxidant and free radical scavenging activity of extracts of Rosa damascena flower petals. American Journal of Phytomedicine and Clinical Therapeutics, 3(9):589-601.

Prahastuti, S., Hidayat, M., Hasianna, S. T., Widowati, W., Amalia, A., Yusepany, D. T., Rizal, R., \& Kusuma, H. S. W. (2019). Antioxidant potential ethanolic extract of Glycine max (L.) Merr. Var. detam and daidzein. Journal of Physics: Conference Series, 1374(012020):1-13

Prahastuti, S., Hidayat, M., Hasiana, S. T., Widowati, W., Widodo, W. S., Handayani, R. A. S., Rizal, R., \& Kusuma, H. S. W. (2020). The ethanol extract of the bastard cedar (Guazuma ulmifolia L.) as antioxidants. Pharmaciana, 10(1):77-88.

Pujimulyani, D., Suryani, L.Ch., Setyowati, A., Handayani, Rr., A.S., Arumwardana, S., Widowati, W., Maruf, A. (2020). Cosmeceutical potentials of Curcuma mangga Val. extract in human BJ fibroblasts against MMP1, MMP3, and MMP13. Heliyon, 6(e04921):1-6

Rakhshandeh, H., Vahdati-Mashhadian, N., Dolati, K., \& Hosseini, M. (2008). Antinociceptive effect of Rosa damascena in mice. Journal of Biological Sciences, 8(1):176-180.

Rozalia, M., Vasiliki-Ioanna, B., Evanthia, D., Nektarios, A., \& Alexios-Leandros, S. (2016). Greek flora as a source of new antioxidant, anti-elastase, anti-collagenase and anti-hyaluronidase natural agents. Planta Medica, 81(S 01): S1-S381.

Scotti, L., Singla, R. K., Ishiki, H. M., Júnior, F. J. B. M., Silva, M. S. da, Filho, J. M. B., \& Scotti, M. T. (2016). Recent Advancement in Natural Hyaluronidase Inhibitors. Current Topics in Medicinal Chemistry, 16(23):2525-2531.

Shameh, S., Alirezalu, A., Hosseini, B., \& Maleki, R. (2019). Fruit phytochemical composition and color parameters of 21 accessions of five Rosa species grown in North West Iran. Journal of the Science of Food and Agriculture, 99(13):5740-5751.

Schmitzer V, Veberic R, Osterc G, Stampar F. (2009). Changes in the phenolic concentration during flower development of Rose' KORcrisett'. Journal of the American Society for Horticultural Science, 134(5):491-496.

Stevenie, S., Girsang, E., Nasution, A. N., \& Lister, I. N. E. (2019). Comparison activities of peel and extract of lime (Citrus amblycarpa) as antioxidant and antielastase. American Scientific Research Journal for Engineering, Technology, and Sciences (ASRJETS), 57(1): 77-84.

Tatke, P., Satyapal, U. S., Mahajan, D. C., \& Naharwar, V. (2015). Phytochemical analysis, in-vitro antioxidant and antimicrobial activities of flower petals of Rosa damascena. International Journal of Pharmacognosy and Phytochemical Research, 7(2):246-250.

Utami, S., Adityaningsari, P., Sosiawan, I., Endrini, S., Sachrowardi, Q. R., Laksono, S. P., Nafik, S., Arrahmani, B. C., Afifah, E., \& Widowati, W. (2017). Antioxidants and anticholinesterase activities of the characterized ethanolic of ripe sesoot (Garcinia picrorrhiza Miq.) fruit extract (GpKar) and xanthone. Majalah Obat Tradisional, 22(3):160-165.

Vrianty, D., Qodariah, R. L., Widowati, W., Sinaga, A. P. F., Fibrina, D., Fachrial, E., \& Lister, I. N. E. (2019). Comparison of Antioxidant and anti-tyrosinase activities of pineapple (Ananas comosus) core extract and luteolin compound. Jurnal Kedokteran Brawijaya, 30(4):240-246

Widowati, W., Fauziah, N., Herdiman, H., Afni, M., Afifah, E., Kusuma, H. S. W., Nufus, H., Arumwardana, S., \& Rihibiha, D. D. (2016). Antioxidant and antiaging assays of Oryza sativa extracts, vanilin, and coumaric acid. Journal of Natural Remedies, 16(3):88-99.

Widowati, W., Rani, A. P., Hamzah, R. A., Arumwardana, S., Afifah, E., Kusuma, H. S. W., Rihibiha, D. D., Nufus, H., \& Amalia, A. (2017). Antioxidant and antiaging assays of Hibiscus sabdariffa extract and its compounds. Natural Product Sciences, 23(3):192-200

Widowati, W., Noverina, R., Ayuningtiyas, W., Kurniawan, D., Faried, A., Laksmitawati, D.R., Rihibiha, D.D., Rizal., R., Suciati, T., Sumitro, S.B. (2018a). Reactive oxygen species and aging mechanism. Book Chapter in Reactive oxygen species (ROS) mechanism and role in health and 
diseases. Editor : Whilkerson, S. Nova Publisher; pp101-134.

Widowati, W., Widya Janeva, B., Nadya, S., Amalia, A., Arumwardana, S., Kusuma, H. S. W., \& Arinta, Y. (2018b). Antioxidant and antiaging activities of Jasminum sambac extract, and its compounds. Journal of Reports in Pharmaceutical Sciences, 7(3):270-285.

Zheng J, Yu X, Maninder M, Xu B. (2018). Total phenolics and antioxidants profiles of commonly consumed edible flowers in China. International Journal of Food Properties,21:1,1524-1540. 